\title{
Leaders Vertical Coordination To Community in The Development Implementation
}

\author{
Nurpeni, Fara Merian Sari \\ Universitas Lancang Kuning \\ e-mail: nurpeni@unilak.ac.id
}

\begin{abstract}
Research with the title Vertical Village Coordinating Leaders to the communityin the implementation of development in the Wonorejo Village Marpoyan Damai District Pekanbaru City was held for about five months, where a phenomenon that often occurs where the problem of floods and accumulated rubbish always becomes an annual problem in the Kelurahan. Besides that, the implementation of community empowerment in the form of skill improvement is still less attractive to the community. This condition is inseparable from the lack of communication by village leaders to the community. The concept of theory in this study refers to the concept of James D. Money in the Shafi Inu Kencana (2011: 35) the elements that exist in coordination include:1. Settings, 2. Synchronization, 3. Common Interests, 4. Common Goals with data collection techniques through observation and in-depth interviews. The type of research is done through a qualitative descriptive approach. The results of the study showed that there was a lack of public knowledge about regulation, synchronization, shared interests and shared goals, this was due to the lack of communication by village leaders to the community and also the lack of socialization about the importance of environmental cleanliness.
\end{abstract}

Keywords: Coordination, Vertical, Village Leaders

\begin{abstract}
Abstrak
Penelitian dengan judul Pemimpin Koordinasi Desa Vertikal kepada masyarakat dalam pelaksanaan pembangunan di Desa Wonorejo Kabupaten Marpoyan Damai Kota Pekanbaru diadakan selama sekitar lima bulan, dimana fenomena yang sering terjadi dimana masalah banjir dan penumpukan sampah selalu menjadi masalah tahunan dalam kelurahan. Selain itu, implementasi pemberdayaan masyarakat dalam bentuk peningkatan keterampilan masih kurang menarik bagi masyarakat. Kondisi ini tidak terlepas dari kurangnya komunikasi oleh para pemimpin desa kepada masyarakat. Konsep teori dalam penelitian ini mengacu pada konsep James D. Money dalam Shafi Inu Kencana (2011: 35) unsur-unsur yang ada dalam koordinasi antara lain: 1. Pengaturan, 2. Sinkronisasi, 3. Minat Bersama, 4. Tujuan Bersama dengan teknik pengumpulan data melalui observasi dan wawancara mendalam. Jenis penelitian dilakukan melalui pendekatan deskriptif kualitatif. Hasil penelitian menunjukkan bahwa kurangnya pengetahuan publik tentang regulasi, sinkronisasi, kepentingan bersama dan tujuan bersama, ini disebabkan oleh kurangnya komunikasi oleh para pemimpin desa kepada masyarakat dan juga kurangnya sosialisasi tentang pentingnya lingkungan. kebersihan.
\end{abstract}

Kata Kunci : Koordinasi, Vertikal, Pemimpin Desa. 


\section{INTRODUCTION}

Coordination is an effort to integrate, harmonize and adapt various interconnected interests and activities to achieve ultimate goals and objectives. Coordination needs to be accomplished, from the arrangement, synchronization, common interests and goals (James D. Mooney in Inu Kencana Syafi'i 2011: 35): Coordination referred to is vertical coordination. Vertical coordination is defined as unification process and management activities conducted by village chief on development activities involving the community in accordance with the development program of the village as shown in the following table:

Table 1.1 Work Program of Wonorejo Village, Marpoyan Damai subdistrict, Pekanbaru City

\begin{tabular}{ccc}
\hline NO & Year & Work Program \\
\hline 1 & 2017 & Conducting Village Program \\
\hline 2 & 2017 & Conducting Village Community Empowerment Activity \\
\hline 3 & 2017 & Conducting Community Service \\
\hline 4 & 2017 & Maintaining Peace and Order in Village \\
\hline 5 & 2017 & Maintaining Cleanliness of Village Area \\
\hline 6 & 2017 & Maintaining Facilities and Infrastructure \\
\hline 7 & 2017 & Maintaining Facilities Quality of Community Service in Village \\
\hline 8 & 2017 & Conducting Related Works \\
\hline
\end{tabular}

Source, Village Office of Wonorejo Village, Marpoyan Damai Subdistrict, Pekanbaru city in 2018

The table above shows the work program of Wonorejo village consisting of the internal work program and external work program of the village. The internal work program contains:

- Conducting Village Program

- Conducting Community Service

- Maintaining Facilities and Infrastructure

- Maintaining Facility Quality of Community Service in Village

- Conducting Related Works

The external work program consists of:

- Conducting Village Community Empowerment Activity

- Maintaining Peace and Order in Village

- Maintaining Cleanliness of Village Area

- Maintaining Facilities Quality of Community Service in Village

- Conducting Related Works

In this study, the work program referred to is the external work program that involves the community in its implementation.

Vertical coordination between village chief and community in conducting development both physical and non-physical development has not been optimal. The most commonly found phenomena are the problem of flooding and mountainous garbage, which have been an annual problem of the Village. Besides, the progress of community empowerment in the form of skill improvement is not attractive enough for the community.

This condition is inseparable from the lack of communication between the village chief and the community. Based on the description above, the researchers conducted research entitled "Leaders Vertical Coordination to Community in the Development Implementation in Wonorejo Village, Marpoyan Damai Subdistrict, Pekanbaru City". The researchers found this title is fascinating not only for the null result of previous research but also for the benefits this study might contribute for the village chief to self-motivate and encourage the community to develop and improve the village. 


\section{METHOD}

According to Bogdan, qualitative data analysis is the process of systematic finding and compiling data obtained from interviews, field notes and other materials to be more understandable and to share findings by organizing data into categories, dividing into units, conducting synthesis, arranging into patterns, and drawing conclusions so it is easily understood by oneself and others (Sugiyono, 2005: 89)..

\section{FINDING AND DISCUSSION}

4.1 Coordination between village chief and the community in the development implementation in Wonorejo Village, Marpoyan Damai Subdistrict, Pekanbaru City.

On the basis, the implementation of development must involve the state apparatus and the community. The form of community participation is usually found in community work activities, providing food during activities, and Ocrowd funding participation for activities held by the village office.

Coordination which is a process of interaction to execute development goals, in this case, the coordination between the village and the community, can be seen from the indicators by Inu Kencana Syafi'i (2011: 35).

The analysis researchers used refers to the concept of Inu Kencana Syafei with indicators of regulation, synchronization, common interests, and common goals. This will be elaborated through interviews, observation, and documentation. Informants in this study consisted of the secretary of the village chief, village staff, Neighborhood I and Community Financial Institution.

1. Secretary of Village Chief

a. Setting

The definition of regulation in this research is the process, method or action of organizing work to be conducted properly so the seized objectives can be achieved. To implement the programs, particularly programs related to the village community, process and its implementation should be arranged together "with related parties". The following is the excerpt from the interview with the informant involved in the arrangements.

"In conducting development, especially the physical development village office does not have a particular program, physical development has been administered by the competent authority. Besides, the village office is incompetent in funding for physical development. Development goes on as is. Specifically for development involving community such as community work, the arrangements are created by the village office and it will coordinate with neighborhood and hamlet in the respective area (Secretary of Wonorejo village, December $19^{\text {th }}, 2018$ )

b. Synchronization

Synchronization is the process of setting up several processes at the same time. The main purpose of synchronization is to avoid the inconsistency of data obtained from several different processes. Following is the result of the interview with informant:

"In order for the program to run well, the village chief will coordinate with the authorities so the implementation runs on its path."

\section{c. Common interest}

Common interest is the foundation of group behavior, the following is the excerpts from the interview with informant: 
"Every planned program to be implemented must be according to the common interest, not merely for personal / group interests".

d. Common goal

The common goal is set target seized on the same target to avoid deviation. The following is an interview excerpt from the informant:

"The implemented program must aim for the common interest and common goal"

From the results of the interview with the secretary of the village office, the coordination between the village chief and the community regarding the development involving the community has been carried out. This can be seen from the enthusiasm of the community to participate.

2. Village staff

a. Settings

The following is the excerpt of the interview with the village staff.

"We discuss or discuss activities organization with the community cooperatively before activities with the community, such as community work, training."

b. Synchronization

"We equate perceptions/views before the implementation of activities. The village chief has a dominant role in order to synchronize."

c. Common interest

"We together with the village chief always prioritize the common interests in carrying out activities."

d. Common goals

"All activities for community activities and common goals with the community".

The conclusion from the interview results is that four research indicators namely regulation, synchronization, common interest, and common goal have been carried out in Wonorejo village.

3. RT I

a. Setting

In certain cases or activities, the village office coordinated with the neighborhood. For example, community work activities, village office would completely hand over to the neighborhood. Recently, there was a training activity and village office coordinated with the neighborhood."

e. Synchronization

We equate perceptions/views before the implementation of activities. Village office has a dominant role in order to synchronize."

f. Common interest

We together with the village chief always prioritize common interest in carrying out activities.'

g. Common goal

All activities for community activities and common goals with the community ".

4. LKM (Community Financial Institution)

b. Setting

"In certain cases or activities, the village office coordinated with the neighborhood. For example, in the activities of community work, the village office would completely hand over to the neighborhood. Recently, there was a training activity and the village office would coordinate with the neighborhood."

h. Synchronization

"We equate perceptions/views before the implementation of activities. The village chief has a dominant role in order to synchronize." 
i. Common interest activities."

"We together with the village chief always prioritize the common interests in carrying out

j. Common goals

"All activities are for community activities and common goals with the community

Conclusions drawn from the results of the interview, coordination depends on the form of activities when community work activities, village office will hand over it to the neighborhood. When it is regarding improving SKILL/community capability, then synchronization arrangements, common interest, and common goal are carried out.

5. Community

"We were enthusiastic when the village office/neighborhood representative made activities related to setting, synchronization, common interest, and common goal, we did not know it".

From the results of the interview with the community, thus the community does not understand the setting, synchronization, common interest, and common goal made by the village office. The community only works from the order of the village office or neighborhood.

\section{CONCLUSION}

Conclusions and results of the study entitled Leaders Vertical Coordination to Community in the Development Implementation in Wonorejo Village, Marpoyan Damai Subdistrict, Pekanbaru City.

1. Village Secretary

From the results of the interview with the village secretary, it can be concluded that the coordination of the village chief with the community related to development involving the community has been carried out. This is shown by the enthusiasm of the community to participate.

2. Staff

The results of the interview conclude that four research indicators namely setting, synchronization, common interest, and common goal have been carried out in Wonorejo village.

3. Neighborhood

The conclusion drawn from the results of the interview is coordination depends on the form of activities when community work activities are held, the village office will hand over it to the neighborhood. When it is regarding improving SKILL/community capability, then setting, synchronization, common interest, and common goal are carried out.

4. Community

From the results of the interview with the community, it can be concluded that the village office is lack of socialization to give proper understanding to the community about the importance of togetherness to build the village.

5. Community Financial Institution

The conclusion from the results of the interview, coordination depends on the form of activities when community work activities are held, the village office will hand it over to the neighborhood. When it is regarding improving SKILL/community capability, then setting, synchronization, common interest, and common goal are carried out. 


\section{SUGGESTION}

The village office should intensify its coordination with the community in the implementation of development. The community should not only be involved in carrying out its development activities, but also involved in setting, synchronization, common goal, and common interest

\section{BIBLIOGRAPHY}

[1]. Dwiyanto , A. Partini, Ratminto, Wicaksono, B. Tamtiatani, W. Kusumasari, B. Nuh M, 2009, Reformasi Birokrasi Publik Indonesia, Pusat Studi Kependudukan dan Kebijakan Universitas Gajah Mada, Yogyakarta

[2]. Hamim, Sufian, 2009. Organisasi, Administrasi dan Manajemen, Pekanbaru, UIR Press

[3]. Hesel Tangkilisa dan Nogi.2005 Manajemen Publik .Penerbit Raja Grafindo Jakarta

[4]. Karbun , 2013 Kamus Manajemen Pustaka Harapan Jakarta

[5]. Pasolong Harbani, 2008, Kepemimpinan Birokrasi, CV. Alfabeta, Bandung.

[6]. Handoko, T, Hani, 1995. Manajemen Personalia Dan Sumber Daya manusia. Yokyakarta, BPFE.

[7]. Handoko, T, Hani, 2003. Manajemen Edisi 2. Yokyakarta, BPFE YK.

[8]. Saputra, T., Marlinda, P., \& Sufi, W. (2018). Pengaruh Gaya Kepemimpinan Transformasional Terhadap Efektifitas Kinerja Pegawai Puskesmas Rawat Inap Sidomulyo Barat Kota Pekanbaru. Jurnal Niara, 9(1), 13-23.

[9]. Simanjuntak Payaman2011,Manajemen dan Evaluasi Kinerja ,Penerbit Lembaga Penerbit FEUI

[10]. Sugiono, 2010. Metodologi Penelitian Administrasi, Jakarta, Bumi Aksara.

[11]. Sujianto, Ikhsan, \& Syofian. (2019). Strengthening Institutions In The Effort Adat Customary Law Enforcement In Illegal Gold Mining Areas Affected. Jurnal Niara, 12(1), 19- 28. https://doi.org/10.31849/nia.v12i1.2284

[12]. Mangkunegara ,2015.Manajemen Sumber Daya Manusia,Penerbit Remaja Rosda Jakarta

[13]. Mangkunegara, 2015 Evaluasi Kenerja Sumber Daya Manusia,Penerbit Refika Aditama Jakarta 